\title{
Myth-Busting and Entrepreneurship Policy: The Case of High
}

\section{Growth Firms}

Ross Brown, Suzanne Mawson, and Colin Mason

This article has been accepted for publication in Entrepreneurship and Regional Development, published by Taylor and Francis.

\section{Abstract}

Promoting high growth firms (HGFs) has become a strong fixation within enterprise policy. This is a debate article seeking to examine and challenge the mythology perpetuated by policy makers and embedded within high growth entrepreneurship policy frameworks. Within the article we argue that a number of distinctive 'myths' have become deeply embedded within these policy frameworks. Such myths have been built on misconceived preconceptions of HGFs, which has resulted in policy-makers taking a myopic view of these firms. A key aim of the paper is to highlight how false perceptions of HGFs translate into inappropriate policy interventions. The paper challenges some of the most commonly held myths about these firms (that they are predominantly young, small, high-tech, VC-backed, university spin-outs, who grow in an orderly organic fashion, operating similarly irrespective of location) and identifies a clear mismatch between how policy makers perceive HGFs and what they actually look like in reality. Suggestions for the design of future policy approaches are forwarded.

\section{Key Words}

Myths 


\section{Introduction}

Within the intellectual domain of entrepreneurship, "several pseudoscientific myths have developed" (Zahra and Schulte 1994, 86). Importantly, these myths can also influence policy priorities (Gibb 2000; Xheneti, 2016). Due to this, Rehn et al. $(2013,544)$ claim it is important scholars are able to challenge the "most valued assumptions and subject these to critical scrutiny". Taking up this challenge, this paper examines a number of key myths surrounding high growth firms (henceforth HGFs), famously christened 'gazelles' by David Birch (1981), perpetuated by policy makers. The central contribution of this debate article is to challenge the myths embedded in policy making and to examine how these myths translate into misconceived policy approaches.

In recent years, HGFs have become something of the 'fixation' within enterprise policy and are widely perceived to be critical for economic development (Acs et al. 2008; Shane 2009; Mason and Brown 2013; Bos and Stam 2014; Lee 2014; Autio and Rannikko 2016). According to some, it is hard to overstate the impact of Birch's original work on gazelles for policymaking organisations such as the US Small Business Administration (Welter et al. 2016). As Rehn et al. $(2013,547)$ note, there is an ongoing "fascination with high growth companies" within the policy community. The primary attraction of HGFs owes to their perceived ability to create 'jobs' (Henrekson and Johansson 2010; Coad et al. 2014). In the UK, for example, research has found HGFs generate over half of all net new jobs despite representing a mere $6 \%$ of the business base (Anyadike-Danes et al. 2009). Similar studies in the US (Decker et al. 2015) and several European economies have replicated these findings (Brüderl and Preisendörfer 2000; Deschryvere 2008). Such 'job creation' studies have helped to foster a burgeoning body of empirical research on HGFs (Henrekson and Johansson 2010), thus generating continued debate on their economic impact and the capability of policy makers to generate and support them (BERR 2008; Shane 2009; Greene 2012; Lee 2014; Nightingale and Coad 2014; Brown and Mawson, 2016a). 
This paper contends, however, that high growth entrepreneurship policy remains underpinned by a number of pervasive 'myths' which have become deeply engrained in policy frameworks. In other words, within the policy community there seem to be very strong preconceived views of what HGFs look like and what assistance they require. This situation is reminiscent of the 'Blind Men and the Elephant' story outlined by Gartner (2007), where various blind men touch different parts of an elephant and come away with very different views of an elephant's characteristics. A similar situation exists with policy maker perceptions of HGFs. Gartner (2007) notes that some entrepreneurship scholars are not conscious of their own "blind assumptions". We contend that this equally applies to policy makers. It is our belief that their views are strongly predicated on various 'blind assumptions' that do not match empirical reality. Consequently, policy makers are often "looking in the wrong places for such firms" (Mason and Brown 2013, 214).

There are various explanations for this perceptual mismatch that underpins the process of HGF 'myth-building'. It may be due in part to the actions of so-called 'policy entrepreneurs' (Kingdon 1984), key actors with a vested interest in particular policies (Flanagan et al. 2011). Hirunyawipada and Paswan $(2013,2333)$ claim that the ideas of many practitioners are inevitably "based on their past experiences", which in turn leads to people sticking "to their tried and tested mental models". Through the actions of policy entrepreneurs, certain beliefs can quickly become embedded within public policy without any explicit acknowledgement or reasoning (Brown 2016). There appears to be an institutional logic (Friedland and Alford 1991) amongst these policy entrepreneurs of what HGFs look like, what their economic benefits are, and how best to foster them, which exists independently of - and sometimes in contrast to - the developing evidence base. ${ }^{1}$

Another possible explanation for 'myth-building' within public policy centres on the selective use of empirical evidence. Due to the so-called 'rigour-relevance gap', connectivity between scholarly entrepreneurship research and practice is low (Frank and Landström, 2016). Therefore, while the empirical literature surrounding HGFs has expanded considerably over

\footnotetext{
${ }^{1}$ Such views have arguably been further propagated by the wider 'high growth firms industry', comprising, inter alia, the OECD, government policy makers, think tanks such as Nesta and the Kauffman Foundation, funding organisations, economic development agencies, consultants, intermediaries (corporate lawyers etc.) and university technology transfer offices (TTOs).
} 
the last decade, assumptions about these firms within public policy have failed to catch-up with the expanding evidence. This may also hinge on the fact that the bulk of entrepreneurship research continues to focus on high-growth, technology-enabled, venture capital-backed businesses such as Apple, Google and Amazon (Welter et al. 2016). Scholars are critical of the over-emphasis on this "Silicon Valley model of entrepreneurship", which in actual fact constitutes a "tiny group of outliers" yet drives much of "the direction of recent public policy" (Welter et al. 2016, 2-3).

Nightingale and Coad $(2014,124)$, note that bias within entrepreneurship research is largely driven by "demands for positive evidence which create a shift toward increasingly positive interpretations as one moves from analysis, through the grey literature, to policy." The logical consequence of this is that the evidence base is often used selectively by policy makers to justify specific actions and interventions, rather than as a theoretical foundation upon which to build and develop appropriate interventions from the 'bottom-up'. So, whilst the evidence base surrounding HGFs remains incomplete, policy makers have tended to adopt a highly selective approach when drawing on it for policy development. This is evidenced in policy documentation and outputs through the continued reliance on select (sometimes outdated) sources of literature and evidence. This results in the creation of policy frameworks and support mechanisms that are often misguided and fail to effectively provide appropriate support to the specific needs of growing firms (Nightingale and Coad 2014).

This is not a conventional paper. While certain myths associated within scholarship on rapid firm growth have been highlighted (Kiviluoto, 2013), this paper specifically focuses on the misconceptions within public policy. Indeed, following others (Power and Malmberg 2008; Brown 2016), this is a debate article seeking to examine and challenge the mythology perpetuated by policy makers and embedded within high growth entrepreneurship policy frameworks. It is not intended to be a comprehensive meta-analysis of the HGF literature, but rather a critical assessment of current HGF policy closely linked to a rigorous review of the current empirical literature base on HGFs. Arguably, the nascence of the literature has allowed a gap to exist between the empirical reality of HGFs and policy makers' perceptions of them. This disconnect may in part explain why a number of myths within the policy making community continue to hold sway over current rhetoric and interventions. This paper 
therefore makes an important contribution to both the HGF literature and the entrepreneurship policy literature by highlighting how certain assumptions become translated into inappropriate policy initiatives.

Given space constraints, our focus will be limited to the myths and evidence base pertaining to the specific nature or characteristics of HGFs themselves. This part of the HGF phenomenon is of particular importance to high growth entrepreneurship policy formulation and implementation, particularly given the focus on how these firms can be developed and cultivated. Indeed, these characteristics are often used as implicit forms of policy targeting. The central question guiding this paper is "what are the main myths associated with HGFs within high growth entrepreneurship policy and what impact have these had on the entrepreneurship policy domain"?

Whilst in essence a debate article, it is strongly evidence-based and draws on three main sources of empirical evidence. First, the researchers undertook a rigorous review of existing empirical studies on the nature and characteristics of HGFs. The review examined the literature on HGFs, but concentrated on studies published since the previous meta-analysis of this field in 2010 (see Henrekson and Johansson 2010). To be included, studies needed to be empirical papers, written in English, published in peer reviewed journals and had to be focused specifically on HGFs. Other key words such as 'high-impact', 'rapid-growth' and 'gazelle' were also included in search terms. Second, a similar review of policy programmes was conducted which focused on interventions and frameworks specifically targeting HGFs (or using the other key words above) (Brown et al, 2017). Policy documents and economic strategy documents serve as a proxy for understanding institutional logic amongst policy makers. Documentation was required to be published in English, with no limitations placed on country of origin. The majority of policy documents came from OECD countries. Additionally, the eligibility criteria in various high growth programmes were examined. While this information is not always easy to obtain for all programmes, many support agency websites outline their criteria for inclusion on programmes. Finally, the paper also draws on a large programme of qualitative research conducted by the authors between 2008-2014, which included more than 50 interviews with Scottish HGFs and 20 interviews with policy makers. These interviews were further augmented by work undertaken by the authors for 
the LEED programme of the OECD on different policy approaches designed to support HGFs (OECD 2013).

The remainder of the paper is structured as follows. It begins with a discussion of definitional issues, followed by some of the key features of the HGF literature. We then review the empirical evidence base on the nature and characteristics of HGFs, linking findings to a number of key myths that are predominant within high growth entrepreneurship policy. The paper then provides a discussion of the implications of recent HGF studies for the current shape of policy. Finally, conclusions and suggestions for further research are highlighted.

\section{Definitional Issues}

Owing to the fact that HGFs can be measured in different ways (Moreno and Coad 2015), there is ongoing debate over the merits and drawbacks of different definitions (Coad et al. 2014; Daunfeldt et al. 2014; Lee, 2014; Anyadike-Danes et al. 2015). Whilst this debate is not the focus of this paper, definitional issues are important because conceptions of business growth vary markedly between scholars and practitioners (Achtenhagen et al. 2010). We wish to argue that perceptions of business growth also appear to differ between scholars and policy makers. Indeed, much of the early literature failed to use a consistent metric for measuring firm growth (Henrekson and Johansson 2010), drawing on a range of metrics such as employment, turnover and assets (Delmar et al. 2003). Since the mid-2000s, however, there have been concerted moves by the OECD to standardize the way in which HGFs are formally defined and identified. Under the OECD's definition, a HGF is considered to be 'an enterprise with average annualised growth (in number of employees or turnover) greater than $20 \%$ per annum, over a three year period, with a minimum of 10 employees at the beginning of the growth period' (OECD 2008, 61).

As with any standardized definition, a number of problematic issues have been raised. Key concerns are that the definition omits firms which may be growing rapidly but fall just outside this exacting growth threshold (Anyadike-Danes et al. 2015); turnover and employment do not necessarily reflect how entrepreneurs themselves conceptualise growth (Achtenhagen et al. 2010); and that the mathematics of percentages biases the measure towards smaller - and hence newer - businesses. There is also concern over what should be measured. While 
studies have found a link between employment growth and turnover growth measures (Coad 2007), others find that different definitions and measures identify different groups of firms (Daunfeldt et al. 2014), which potentially has significant implications for policy development. Although many early studies focused on growth in employment (Anyadike-Danes et al. 2009), there is now an increasing use of growth in turnover as a means of defining HGFs (e.g. Mason and Brown 2013; Du and Temouri 2015). Given that this metric overlooks profitability, some have strongly challenged whether sales growth is in fact a suitable measure of firm "success" (Kiviluoto, 2013). Despite its criticisms, the OECD measurement criteria has merits in terms of providing a foundation for comparability amongst studies and has been widely used in recent years by both researchers (e.g. Mohr et al. 2014; Brown and Mawson 2016b) and policy makers. Interestingly, some policy makers have adjusted the OECD measurement criteria to reflect the nature of their local economy (DETINI, 2014). ${ }^{2}$

Irrespective of the definition and measurement criteria used to identify HGFs, it is important to note that rapid growth is highly episodic in nature (Garnsey et al. 2006) and thus the population of HGFs is constantly fluctuating. High growth is rarely persistent in firms (Nicholls-Nixon 2005; Hölzl 2014) and therefore high growth in one period of time does not guarantee sustained high growth (Coad et al. 2013; Daunfeldt and Halvarsson 2015). Hence, it is crucial to bear in mind that high growth is not a 'characteristic' of a sub-set of firms, but rather a state that some firms temporarily experience (Brown and Mawson 2013). This means that HGFs are effectively a 'moving target', making them a difficult cohort of businesses for researchers (and policy makers) to identify and target, particularly before a period of high growth commences (Freel 1998). As a result, many studies have focused on identifying, counting and investigating HGFs ex-poste. This has, in some respects, left the high growth entrepreneurship literature theoretically and empirically underdeveloped (Leitch et al. 2010; Demir et al. 2016), which has in turn allowed for myths held within high growth entrepreneurship policy circles to become further entrenched.

\footnotetext{
${ }^{2}$ In Northern Ireland, for example, policy makers decided to remove the minimum employment threshold of 10 employees owing to the extremely low proportion of small and medium-sized enterprises within the local economy which is dominated by micro enterprises (DETINI, 2014).
} 


\section{Recent High Growth Firm literature}

As noted, a key feature of the high growth entrepreneurship literature, and firm growth research more generally, has been a strong focus on the questions of 'how many' and 'how much', rather than questions of 'how' and 'why' firms achieve growth (Henrekson and Johansson 2010; Leitch et al. 2010; McKelvie and Wiklund 2010). The consequence of this focus on measurement is that "our current understanding remains limited" (Dobbs and Hamilton 2007, 315). Indeed, a major review of the empirical research on firm growth concluded that the "stochastic part of the variation by far outweighs the systematic part. In other words, explained variance in growth research is notably low" (McKelvie and Wiklund $2010,277)$. Thus, some observers claim that deciphering the causal factors underpinning rapid firm growth is as random as a 'coin toss' (Coad et al. 2013) and that growth "remains something of an enigma" (Roper and Hart 2013, 11). This myopic focus on HGF growth rates has also largely overlooked crucially important aspects of firm growth, notably firm profitability and sustainability (Brännback et al. 2013) and wider productivity (Daunfeldt et al. 2014).

Despite these oversights, the on-going development of the HGF literature has enabled us to speak with increasing confidence about what HGFs are and, more importantly, what they are not. A key initial observation from the empirical findings concerns the 'pervasive heterogeneity' within growing firms (Coad 2009). There is no such thing as a 'typical' HGF: these businesses are of varying ages and sizes, operate across a range of sectors, exhibit a variety of business models, management styles and ownership structures and achieve growth through a number of mechanisms and channels (Mason and Brown, 2013). The antecedents of growth are equally diverse and complex (Brown and Mawson 2013). It is important to note that the overwhelming majority of studies have been conducted in North America and Europe. Although some work has been done in China (Zhang et al. 2008), sub-Saharan Africa (Goedhuys and Sleuwaegen, 2010) and New Zealand (Hinton and Hamilton 2013; Satterthwaite and Hamilton, 2016), the current conceptualisation (and understanding) of HGFs is very much predicated on observations from a very limited number of similar (i.e. advanced industrial) economies. HGFs in developing or transition contexts are recognised to differ somewhat from those within OECD countries given issues like institutional factors (Krasniqi and Desai, 2016) and thus require further investigation. 
So what else does the literature on the nature of HGFs tell us? Research has strongly corroborated the role of HGFs as job creators, with a meta-analysis of the empirical evidence base concluding that this is perhaps the most unambiguous finding across most of the high growth literature (Henrekson and Johansson 2010). There is now, however, evidence to suggest that employment effects from growth are less straightforward than previously assumed, particularly if acquisition is involved (Daunfeldt et al. 2015a). According to observers, "at the macro level, growth by acquisition may simply 'transplant' jobs from a smaller firm into a larger acquiring firm, thus leading to net zero employment gain" (McKelvie and Wiklund 2010, 282). Although some exceptions exist (Deschryvere 2008), quantitative studies have been largely unable to distinguish between firms that grow organically and those that grow through acquisition, although there is increasing recognition in the literature that some HGFs choose to actively pursue growth via acquisition (Mawson and Brown, 2016).

Few studies have tracked where HGFs are creating jobs, but recent work suggests the geography of job creation in these firms is far from straightforward (Brown and Mawson 2016b). It has been noted that HGFs are likely to operate from multiple locations, often in different countries (Mason et al. 2015), which has implications for the geography of where jobs are located. This means that HGFs might not be as significant job creators in their local 'home' regions or economies after all (Brown and Mawson 2016b). Future research on HGFs therefore needs to clearly differentiate between the gross and net impact of HGFs, including geographical considerations, and also their direct and indirect contributions to employment, which all have critical implications on the actual impact of these firms in job creation and wider economic development and productivity (Daunfeldt et al. 2014).

Despite these emerging empirical insights, our knowledge of the nature of HGFs remains nascent (Demir et al. 2016) and the high growth entrepreneurship literature base needs further development (Coad et al. 2014). While the evidence base has helped to inform new strands of HGF research - and fostered continued conceptual development from HGF researchers - findings have not always been well utilised by policy makers. Of course, the extreme diversity of HGFs creates difficulties for policy makers (Nightingale and Coad 2014) on account of their obsession with designing interventions that target specific types of firms, 
typically according to sector (Lee 2014). As a result, many of the assumptions and findings from the very early HGF literature, even dating back to David Birch's seminal studies in the 1970s and 80s (Birch, 1979; 1981), have continued to dominate policy discourse and development, despite new (and sometimes contradictory) findings emerging. An example of this is the continued focus by policy makers on start-ups generally, despite the evidence showing most start-ups generate little in the way of economic value commensurate with the value of the support they receive (Atherton 2006; Shane 2009; Fritsch and Storey 2014; Mason and Brown, 2014).

\section{The 'Vital Myths' Surrounding HGFs}

It appears that certain myths have taken hold within the policy community about the nature of HGFs, perhaps stemming from the implicit assumptions held by policy makers. These have become deeply embedded in the policy community and have in turn strongly shaped the design of interventions designed to foster and support HGFs. Having extensively reviewed policy documentation pertaining to HGFs, as well as having conducted numerous interviews with policy makers, we identified seven key 'myths' that are explicitly and implicitly embedded within the policy discourse surrounding HGFs.

Whilst this list is not intended to be exhaustive - there are other pervading 'myths' and logics which could also be addressed - these appear to be particularly influential institutional logics within the HGF policy sphere, which have had significant influence on the shape and scope of current HGF policy frameworks and interventions. It is important to note that not all these myths are universally adopted by all policy makers in all institutional contexts, but from our review these are the most common and pervasive myths still actively influencing HGF policy. We now examine each of these myths in turn. Whilst we attempt to critically assess each myth and its policy impact, our purpose is not to provide a balanced review of the literature, but rather to explore the impact of these myths in terms of the design of policy instruments.

\section{Myth \#1 HGFs are all young and small}

Given that interest in HGFs stemmed from the observation that young, small fast-growing firms created the bulk of jobs (Birch 1979; 1981), it is unsurprising that HGFs remain 
conceptualised within policy circles as being dynamic young ventures. For example, policy makers in New Zealand still hold to the belief that "High-growth businesses are often small or young businesses" (Ministry of Business, Innovation \& Employment 2013, 6). Age and size are often conflated by policy makers, despite being discrete (if related) concepts. Part of the explanation for this is that many studies have focused on the relative growth of firms, which tends to oversample smaller firms - growth of $20 \%$ is clearly easier for a small operation than it is for a larger one. A number of empirical studies have also demonstrated the importance of new/young firms as contributors to the cohort of HGFs. Indeed, the first meta-analysis of the empirical HGF literature found that HGFs tend to be younger on average (Henrekson and Johansson 2010).

As the literature base develops, however, is has become increasingly apparent that policy assumptions about HGF age and size do not always hold true. Indeed, Birch himself noted that "gazelles move between small and large quickly - at various times in either direction and to classify them by their size is to miss their unique characteristics" (Birch and Medoff, 1994, p. 163). In a recent review of the high growth literature, one scholar noted that the HGFs accounting for most employment growth "tend to be larger and more mature" (Audretsch, 2012, p. 29). Recent evidence further indicates that the majority of HGFs are in fact older and larger than previously believed. Research in the US found that HGFs are on average 25 years old and that even smaller HGFs (employing 1-19 employees) exhibited a more advanced average age of 17 years (Acs et al. 2008). In the UK, it has been found that $70 \%$ of HGFs are at least five years old (NESTA 2009), while survey-based research in Scotland identified that some HGFs are over 25 years old (Mason et al. 2015). Across Europe, similar findings have occurred: Danish HGFs were found to have a mean age of 13 years (Senderovitz et al. 2015) and a Spanish study found no bias towards younger firms amongst Spanish HGFs (Segarra and Teruel 2014).

Another interesting observation relates to the age of the entrepreneurs running HGFs. While some early work found the founder's age to be negatively correlated with rapid growth (Brüderl and Preisendörfer 2000), a recent study found that the average age of entrepreneurs in HGFs is significantly more than 40 years (Senderovitz et al. 2015). Recent interview-based studies conducted in the UK corroborate that these entrepreneurs tend to be older and more 
experienced than in common depictions of fast-growing start-ups (Mason et al. 2015). This chimes with a range of empirical studies demonstrating the vital importance of pre-existing experience and relational connections in boosting firm performance (Nicholls-Nixon 2005; Moreno and Casillas 2007). Indeed, one important spillover from experience is the ability to convince investors of the credibility of the venture's future growth prospects (Barringer et al. 2005). Many high growth programmes, however, continue to specifically target de novo entrepreneurs with little or no experience (OECD 2013). A good example being the High Growth Spin Out Programme operated by Scottish Enterprise, which specifically targets (mostly young) university academics to help commercialise novel intellectual property (IP), most of whom have no prior entrepreneurial (or indeed private sector) experience.

The empirical evidence challenges the assumption by policy-makers that firms (and by extension entrepreneurs) need to be young or small to achieve significant growth and raises important questions about how policy-makers can best identify, target and support older and more established growth-oriented entrepreneurial firms. Much of the support which falls under the heading of support for 'high growth entrepreneurship' typically targets very young, early stage enterprises and young entrepreneurs (OECD 2013) as reflected in a range of publicly-funded business incubators and growth accelerators evident in most OECD economies (Smallbone et al. 2002; OECD 2013). Plus, many high growth programmes, such as the NIY programme operated by Tekes in Finland, have explicit age criteria stipulating participant firm age which, in the case of Tekes, must be less than five or six years (Autio and Rannikko 2016). ${ }^{3}$ Yet, given that many HGFs emerge out of well-established firms, much of the 'future HGF' base are not eligible for these programmes and fall outside the remit of business incubators, business planning and start-up services and small-scale (or seed) start up financing. This creates a mismatch between the support systems in place and the target market of a vast number of potential HGFs. Indeed, the dynamics of micro-firms are recognised to "differ markedly from those associated with their high-potential counterparts" (Lerner 2009, 6). Therefore, conflating the two is bad public policy (Shane 2009).

\footnotetext{
${ }^{3}$ It is worth noting that some high growth programmes do encourage participation by more mature companies, such as the Growth Firm Service in Finland (Autio et al. 2007). This programme offers a one-stop-shop for a range of different support agencies in Finland.
} 


\section{Myth \#2 HGFs are predominantly high tech}

Despite significant academic and policy interest in technology-based or 'high tech' firms (Brown and Mason 2014), the empirical evidence emphasises that HGFs are not synonymous with high tech industries (Brännback et al. 2011; Vanacker and Manigart 2010; Daunfeldt et al. 2015b). This is not to say that some high-tech firms will not eventually become HGFs - this is clearly not the case, especially in dynamic regional economies with strong levels of entrepreneurship and institutional conditions to promote technology companies such as Cambridge or London in the UK. The strong belief within the UK, and indeed most advanced economies (Brown and Mason 2014), that high-tech sectors are significant generators of HGFs is, however, erroneous and misleading (Brännback et al. 2011; Welter et al. 2016). Despite robust evidence to the contrary, "there is still the popular belief among politicians that high tech sectors are the most likely to produce HGFs" (Moreno and Coad 2015, 14).

In the UK, for example, research shows that only around 15\% of HGFs are operating in high tech sectors; this figure is slightly higher for the South East of England at just over 20\%, but for most other regions the prevalence of high tech HGFs is between 12-16\% (Brown and Mason 2014). Similar work in Belgium found that $80 \%$ of HGFs were represented in industries generally considered "low-tech" (Vanacker and Manigart 2010). Many of these firms are found in traditional industries, such as construction and manufacturing, as well as business and personal services. A number of studies have identified that HGFs are overrepresented in services compared to other sectors (Henrekson and Johansson 2010), especially knowledgeintensive services (Daunfeldt et al. 2015b). The wide distribution of HGFs across different sectors, combined with the lack of a link between HGFs and high-tech sectors, holds for most countries (Bleda et al. 2013) and thus it is important to emphasise the sectoral heterogeneity of HGFs.

It is possible that policy makers have crudely equated 'high-tech' with levels of innovativeness within firms, as evidenced by the wide range of 'innovation' programmes targeted at HGFs. Yet the majority of recent work shows that HGFs are highly innovative, irrespective of their industrial sector (O'Regan et al. 2006; Segarra, and Teruel 2014). Coad and Rao (2008), for example, found that innovativeness (measured as patents for R\&D spending) is strongly correlated to sales growth in HGFs. The precise nature of their innovation behaviour suggests, 
however, that HGFs may depart from conventional R\&D intensive firms, as the innovative capabilities of these firms are built on the exploration of familiar technologies (Colombelli et al. 2014). This echoes other recent empirical work, which found that HGFs tend not to be disruptive innovators, but rather modifiers of existing technologies (Hinton and Hamilton 2013; Mason and Brown 2013). Similarly, Parker et al. (2010) found that product innovation was negatively associated with becoming a HGF, but an "active use of marketing" was positively linked. Another recent dimension to this debate is the observation that innovation by HGFs is heavily mediated by the nature of the competitive environment within which individual firms operate (Mazzucato and Parris 2015).

Despite the empirical evidence, many HGF policy interventions remain focused on high-tech firms and have criteria explicitly favouring inclusion of these companies. In the Netherlands, for example, most high growth programmes are aimed at "innovative small firms and technostarters", with the TechnoPartner programme a core offering targeting "high-tech start-ups" (Scales 2007,15$)$. This emphasis is often reflected in programme eligibility criteria. For example, the aforementioned NIY programme operated by Tekes in Finland requires participants to have a minimum expenditure of $15 \%$ of turnover on R\&D (Autio and Rannikko 2016). Similarly, the High Growth Start-up Unit operated by Scottish Enterprise has explicit eligibility criteria stating "your business needs to be commercialising potentially disruptive intellectual assets that are likely to achieve revenues of $f 5$ million within five years". ${ }^{4}$ Given the nature of R\&D focused innovation support, this will strongly favour high-tech firms at the expense of firms that are innovative in a wider sense, thus potentially overlooking a large proportion of HGFs. In New Zealand, for example, some analysis shows that the single largest expenditure area of high growth policy is business R\&D grants, which accounts for around $40 \%$ of overall expenditure aimed at fostering HGFs. ${ }^{5}$

In terms of future policies designed for HGFs, given that genuinely 'high tech' firms comprise only a small part of the HGF base, policy interventions aimed at this sector (e.g. R\&D assistance for product innovation) could be scaled back accordingly, allowing for greater

\footnotetext{
4 This quote was taken from the Scottish Enterprise website: https://www.scottish-enterprise.com/services/support-forentrepreneurs/high-growth-support/are-you-eligible

${ }^{5}$ Ministry of Business, Innovation \& Employment, (2013) High-growth businesses in New Zealand
} 
resources to be allocated to different types of marketing-related support for firms across a variety of industry sectors to best support the HGF population as a whole. Other more broadly focused sectors, such as business services, might pose "better opportunities" for targeted firm growth support (Buss 2002, 18).

\section{Myth \#3 Universities are a major source of HGFs}

Related to the myth of high tech, there appears to be an entrenched belief within public policy that universities play a strong role in generating HGFs (Power and Malmberg 2008; Brännback et al. 2011). Policy makers now view universities as a core part of their high growth entrepreneurship policies (Brown and Mason 2014). This is evident in the provision of considerable funding dedicated towards creating entrepreneurial universities through activities such as incubation facilities, spin-out programmes and angel clubs (Audretsch et al. 2016; Brown 2016). In Germany, for example, the government-funded EXIST programme aims to promote technology and knowledge-based start-ups through innovation grant funding. ${ }^{6}$ University-based spinouts (USOs) are observed by policy makers as an economically powerful subset of high technology start-ups, providing a key conduit for the creation of new high-tech firms (Rothaermel et al. 2007). Despite this belief, the evidence strongly indicates that very few USOs grow and the vast majority remain very small (Harrison and Leitch 2010). Following a major investigation into the sources of high growth in the Scottish economy, researchers concluded that "very few university spin-offs become high growth firms" (Brown and Mason 2014, 780). Indeed, recent comparative research on USOs and company spin-offs (CSOs) found that the performance of CSOs in terms of sales growth and survival rates is considerably higher (Wennberg et al. 2011). Firms spawned by large corporates are a much more significant source of high growth than USOs, particularly when entrepreneurs have worked in larger corporate environments (Barringer et al. 2005; Wennberg et al. 2011). The evidence suggests that, in most types of entrepreneurial ecosystems, universities will not become a hotbed of rapidly growing entrepreneurial companies (Mason and Brown 2014).

In some instances, moreover, links to local universities make a very small contribution to the knowledge base of HGFs (Mason et al. 2015). For the vast majority of HGFs, universities are

\footnotetext{
${ }^{6}$ http://www.exist.de/EN/Programme/About-EXIST/content.html
} 
rarely used as a key 'source' of innovation (Deiaco et al. 2012). A number of studies show that more important drivers of 'open' innovation for these firms are suppliers, customers and end-users (Wennberg 2013) or even acquired companies (Mawson and Brown 2016). These findings have led some to claim that the significance placed on universities in technology transfer and commercialization policies to generate USOs, or new-starts more generally, has been greatly exaggerated (Harrison and Leitch 2010), especially in peripheral regional economies (Brown 2016). Many of the spin-outs created resemble "science projects" (Bhidé 2008), rather than businesses with growth - let alone high growth - potential. Part of this may stem from the fact that a large proportion of USOs are heavily supported in business incubation programmes via universities and other publicly-funded R\&D support schemes (Bruneel et al. 2012), despite increasing recognition that acceleration rather than incubation models are more appropriate for developing firms with growth potential (Brown and Mawson 2016a). Such intensive early stage support for embryonic business concepts can effectively result in 'killing firms with kindness', preventing them from developing as independent and self-sufficient organisations.

It is important to stress that the role of universities in both fostering and assisting HGFs will be highly context dependent (Welter 2011). While in many cases their role in fostering HGFs may be marginal, as may be their role in knowledge transfer, this situation will vary in different spatial contexts. Compared to peripheral areas, the situation is likely to be significantly different in dynamic entrepreneurial regions that have large research-intensive universities, such as Cambridge in the UK or Boston in the US (Garnsey and Heffernan 2005). Not only do some regions such as these generate more USOs than others, but these kinds of dynamic ecosystems then become magnets for other types of businesses owing to their superior entrepreneurship infrastructure such as access to different sources of funding, acceleration facilities and access to human capital. This would support the fact that the geography of HGFs is often closely linked to key urban population centres, which often feature strong universities (Stam 2005; Rice et al. 2016). Indeed, recent research in the US documenting the locational determinants of HGFs has found them to be linked to locations with higher levels of educational attainment (Li et al. 2016). So while universities may be marginal in terms of their direct contribution to the high growth population, they 
nevertheless play a key role in shaping the overall entrepreneurial ecosystem within which growth-oriented businesses form and grow (Mason and Brown 2014; Spigel 2015).

\section{Myth \#4 HGFs are mostly VC-backed}

Related to the assumptions that HGFs are young and high-tech, they are also perceived within policy circles to require venture capital (henceforth VC) and other forms of entrepreneurial finance such as funding from business angels (see OECD 2011). According to recent research by the World Economic Forum (2014, 92), VC is the type of financing high-growth oriented founders find most "attractive". Indeed, one study examining HGFs in the US and UK bluntly concluded that equity investments are the "most appropriate type of finance for high growth firms" (BERR 2008, 28). Equity finance is also considered "particularly suitable for growing businesses" to enable them to "scale-up up to become the household names of tomorrow" (British Business Bank 2016, 56). This assumption, however, is often misplaced as this view of HGFs is very much influenced by the previous myth that they are concentrated in high tech sectors. For example, this is evident in current VC finance provision in Denmark, operated via the Danish Growth Fund (a state-operated investment fund), which expects participant firms to be companies with "highly innovative products, service, business plan, distribution etc." focused on scaling up in Denmark and internationally. ${ }^{7}$

It has been noted by several authors that relatively little is known about the financial affairs of HGFs (Vanacker and Manigart 2010; Demir et al. 2016). However, recent empirical evidence from the UK indicates that only a tiny fraction of UK HGFs are VC-backed (Brown and Lee 2014). As few as 1-2\% of UK SMEs generally have been found to seek VC or other forms of equity finance (van der Schans 2015). Fifteen years ago, a study of high growth startups found that only $4 \%$ were using venture capital, while the vast majority were either using their own internal funds or conventional debt-finance such as loans (Smallbone et al. 2002). More recently, survey evidence found that a very similar figure of UK high growth SMEs (4.8\%) have been found to utilise risk finance such as venture capital or business angel funding (Brown and Lee 2014). The most common types of finance used amongst these HGFs were banks loans (48.6\%) and bank overdrafts (18.4). Interestingly, the same study found that

\footnotetext{
${ }^{7}$ This quote was taken from the Danish Growth Fund website: http://www.vf.dk/saadan-goer-vi/venturekapital.aspx
} 
HGFs were more reliant on debt-based sources of finance than non-HGF SMEs (Brown and Lee, 2014). Given that these studies have all been conducted in the UK, it would be useful for researchers to examine the prevalence of VC-backed HGFs in other countries.

This does not, of course, deny the crucial role that VC plays in helping to stimulate rapid firm growth within certain types of innovative companies with upside potential (Davila et al. 2003; Audretsch and Lehmann 2004). High-tech R\&D-based start-ups often require equity funding to overcome high levels of informational opacity and a lack of revenue (Berger and Udell 1998). While VC-backed companies constitute a tiny fraction of SMEs, some can become 'blockbuster' success stories such as Apple and Google. ${ }^{8}$ While some of these knowledgebased and technology-based firms tend to exhibit higher rates of growth (Audretsch 2012), these firms are not abundant in most economies. VC-backed firms often comprise a tiny minority of start-ups (Hellmann and Puri 2000). Even in the US, angel finance and VC - at $3.59 \%$ and $1.85 \%$ respectively - represents a relatively small proportion of small business finance (Berger and Udell 1998). Recent data from a Federal Reserve survey in the US shows that risk equity funding is currently used by around $1 \%$ of US SMEs (Miller et al. 2016). ${ }^{9}$ The majority of small firms choose insider sources of finance such as the ' $3 \mathrm{Fs}$ ' - founder, family and friends. Indeed, many entrepreneurs also choose to use bootstrapping techniques like 'bricolage' (Baker and Nelson 2005), creative ways of minimizing or eliminating the need for finance by securing resources at little or no cost, to fund the start-up and early stages of their businesses (Bhidé 1991). These 'lean venture' strategies minimise recourse to external capital in some entrepreneurial firms (Mohr et al. 2014). Evidently, there are many entrepreneurial methods of achieving rapid growth which do not require recourse to equity finance (Welter et al. 2016).

Low usage of VC may be due in part to the heterogeneity of sectors and industries in which HGFs operate, some of which may have limited history of engaging with VC or business angels (consumer services in the sharing economy, for example). Furthermore, a recent study of rapidly growing firms in Cambridge, a very VC-rich environment, found no correlation

\footnotetext{
${ }^{8}$ Berger and Udell (1998) note that during the 1980s approximately $15 \%$ of US IPOs emerged from VC-based firms.

${ }^{9}$ Importantly, in this survey a SME is defined as having less than 500 employees, a substantial departure from the OECD SME definition adopted by most EU countries. Thus, the proportion of smaller firms using this form of finance may be even more limited.
} 
between VC and rapid firm growth (Mohr et al. 2014). The authors of the study speculated that UK entrepreneurs whose firms have good growth prospects avoid VC to prevent dilution of their ownership and control, at the cost of limiting their resource base and growth potential. This has been empirically substantiated in another UK study, which found that rapidly growing firms do not necessarily wish to relinquish ownership to VCs (Parker et al. 2010).

VC is undeniably an important part of the funding ecosystem for many high-tech firms with strong growth ambitions in certain locations (Nightingale et al. 2009; Brown and Mason 2014). It is also much more readily available in certain dynamic geographic contexts (Martin et al. 2005) and is likely more important for firms operating in industries where lean approaches are not realistic (e.g. life science firms, pharmaceutical companies etc.) and funding costs are large. Numerous studies have shown the valuable role VC plays in terms of providing coaching (Baum and Silverman 2004), network development (Shane and Cable 2002) and signalling effects to further investors (Hsu, 2007). Its role in generating rapid growth is, however, difficult to precisely disentangle, leading some to question whether VCs pick or back winners (Baum and Silverman 2004). Indeed, early growth may itself be a factor that attracts venture capitalists, reflecting the "interactive effects that operate in complex dynamic systems" (Mohr et al. 2014, 22).

The empirical evidence overwhelmingly emphasises that the vast majority of SMEs in many developed economies are much more reliant on traditional sources of debt financing for growth (Beck and Demirguc-Kunt, 2006). Indeed, it has been argued that HGFs have lower availability of financial resources (Moreno and Casillas 2007) and may actually incur much greater difficulties raising debt funding than non-HGFs (Lee 2014), although this has subsequently been contradicted by other recent studies (Vanacker and Manigart 2010; Brown and Lee 2014). Interesting recent evidence suggests that rather than being prevented from accessing bank credit, they are more likely to pay higher interest rates on loans than typical SMEs (Rostmakalaei and Freel 2016). While this could reflect the riskier nature of these firms to banks, another explanation in accordance with the "pecking order thesis" of fund raising (Myers and Majluf 1984) is that HGFs may tolerate costlier debt finance over risk equity finance in order to retain ownership of their business. Policy-makers should therefore resist 
the traditional approach of over-emphasising the role of venture capital funds and put greater emphasis on developing a wider range of different types of finance for firms with high growth ambitions. Recognition of the need to boost a wide variety of funding sources should be strongly embodied in organisations such as the British Business Bank.

\section{Myth \#5 HGFs undertake steady linear growth}

A widely held assumption, within the early firm growth literature - which remains evident in policy frameworks and institutional logic to this day - is the mistaken belief that firms typically experience steady linear growth. Dating back to the early 1970s, firm growth was depicted as something akin to the human life cycle, whereupon firms transitioned orderly between set stages from inception to growth, maturity, decline and then death (Churchill and Lewis 1983). This approach became widely embraced by entrepreneurship and firm growth scholars, to the extent that 104 different stage models have been published since the early 1960s (Levie and Lichtenstein, 2010). The life-cycle models reached their peak in the entrepreneurship literature in the mid-1990s (Phelps et al. 2007).

This linear view remains prevalent within the HGF policy community. The vast majority of HGF policy frameworks reviewed demonstrated that programmes are still designed to work through the firm life cycle - from start-up units, leading to growth (or account management) programmes, to finally mature scaling programmes for established organisations. This is currently the approach is use within Scotland through Scottish Enterprise, as well as Northern Ireland via InvestNI. Indeed, simplistic stage growth models are often promoted by scholars to help inform policy makers in the design of their high-growth support activities (see Autio et al. 2007, 12)..$^{10}$

Despite this, in recent years empirical and conceptual papers have strongly questioned the validity of this engrained erroneous belief (Levie and Lichtenstein 2010; Brown and Mawson 2013). While there are some rare examples of firms that can undertake and sustain abnormally high levels of growth for a period of time, these are very much the exception rather than the rule (Satterthwaite and Hamilton, 2016). One of the earliest empirical studies

\footnotetext{
${ }^{10}$ This highlights how myths in the academic world can spill over into the policy world.
} 
of HGFs noted the inner turmoil and sense of infallibility that engulfs firms experiencing rapid growth, increasing the likelihood of failure in these firms (Hambrick and Crozier 1985). Moreover, a considerable amount of research demonstrates that instead of transitioning through relatively orderly growth stages, rapid growth is erratic, unpredictable, sporadic and often of limited duration (Coad 2009). This means that growth is very much a firm-specific process where "periods of growth, plateaus, backslides and changes seem to be distinctive to each enterprise" (Credit Suisse 2012, 5).

HGFs are noted in the literature to undergo longer periods of low or no growth, punctuated by short 'bursts' of rapid growth (Garnsey et al. 2006). Such bursts of growth have been found to result from external growth opportunities or 'growth triggers', rather than being related to a firm's current lifecycle stage (Brown and Mawson 2013). Whilst much firm support is targeted towards firms at an early stage of their life-cycle, the empirical evidence suggests that rapid growth will often occur when firms are more fully developed ventures. Indeed, promoting periods of rapid growth in early stage ventures could have extremely detrimental and unintended consequences for the longer-term survival of some firms. So, while beneficial for some, it can be a "double edged sword" for others (Mohr et al. 2014, 234).

It is therefore essential to reiterate that rapid growth is rarely sustained in the longer term (Hölzl 2014). Indeed, the reverse is often the case: a period of rapid growth can often jeopardise the long-term stability of some ventures (Delmar et al. 2013) especially those firms run by less experienced entrepreneurs or top management teams (TMTs) (Barringer et al. 2005; Nicholls-Nixon 2005). The vast majority of recent work confirms that high growth is not sustainable and that most HGFs are in fact 'one-hit-wonders' (Daunfeldt and Halvarsson 2015). Another recent UK-based study labelled them 'Icarus firms' on account of their susceptibility to liquidate following a period of rapid growth (Lee et al. 2016). While there is little research on the unique managerial challenges confronting HGFs (Wennberg 2013), one study found that firms are unlikely to be successful if they draw lessons from previous growth experiences and try to apply them to different points in time (Parker et al. 2010). Another found that larger TMTs with industry experience in relevant sectors appear to be more capable of coping with the turbulence and unpredictability resulting from rapid growth (Barringer et al. 2005). 
The idiosyncrasies of firm growth patterns and the varied capabilities of TMTs mean that most firms struggle and encounter severe 'growing pains'. Despite this, most policy frameworks are driven to promote rapid growth within firms, irrespective of the longer term consequences. Indeed, some policy makers in New Zealand acknowledge that "some policies to stimulate rapid growth may (inadvertently) increase the volatility of firm performance" (Ministry of Business, Innovation and Employment 2013, 18). The policy landscape, however, remains firmly focused on pushing firms through the key 'lifecycle' stages, rather than taking a more nuanced and firm-specific approach. One exception was the UK's flagship Growth Accelerator programme, which took a more individualistic approach to firm development and growth. It was replaced in early 2016 with a move back to traditional staged funding models via Local Enterprise Partnerships (LEPs). Helping firms manage growth would seem a sensible direction for future policy initiatives, rather just promoting 'high growth' per se.

\section{Myth \#6 HGFs grow organically}

Just as early academic work on firm growth viewed it largely (and in hindsight erroneously) as an incremental or linear occurrence (Levie and Lichstenstein 2010; Brown and Mawson 2013), many policy makers still view growth largely as an organic internally driven phenomenon based on a firm's own internal resource base. As a result, the institutional logic of HGF policy makers, as reflected in policy documents, continues to assume that growth is a simple and linear organic process rather than a result of acquisition or organisational change, with policies designed accordingly to focus on organic growth. This is evident in the typical company building programmes on offer across the world, which aim to build companies from scratch (seed funds, innovation support, premises etc). Recent research suggests, however, that a significant number of HGFs emerge from existing firms that are undertaking a period of organisational change such as a management buy-out (MBO) and management buy-in (MBI) (Mason et al. 2015). Despite this, researchers note that high growth initiatives in the UK have explicitly precluded MBOs and MBIs from participation in these programmes (Smallbone et al. 2002).

This can be linked to the dominant Resource-Based View of early firm growth, which stressed the importance of firms accruing sufficient internal resources before they could grow 
(Garnsey 1998). While organic growth remains the dominant mode of growth for most SMEs, many of whom do not grow, the literature recognises that other models of growth are increasingly utilised by HGFs (McKelvie and Wiklund 2010), although these remain underreported within the literature. ${ }^{11}$ Indeed, another recent study found that entrepreneurial entry via entrepreneurial acquisition was correlated with greater levels of managerial experience (Parker and Van Praag 2012). In other words, growth-oriented entrepreneurs may side-step organic growth via aggressive entrepreneurial expansion through acquisition.

The growing evidence base suggests that this earlier picture of rapid growth as organic and internally generated is somewhat reductionist (McKelvie and Wiklund 2010; Brown and Mawson 2013). Given the heterodox resource needs of most rapidly growing firms, be they technology-related, people-related or finance-related, it comes as little surprise that most firms will seek these resources outside the boundaries of the firm. For example, a significant proportion of UK HGFs are involved in acquisition activity. Looking over the period 20032012 , approximately $20 \%$ of the UK HGFs identified in one study had undertaken one or more acquisitions (Mawson 2012). The majority of these acquisitions were of other UK firms, while $25 \%$ comprised acquisitions of overseas-based firms. Other recent research has also found that UK high growth SMEs were almost four times more likely to undertake an acquisition than non-high growth firms (Brown and Lee 2014). Unquestionably, more research is needed to explore and unravel the relationships between organic and acquisitive growth, particularly from a strategic growth perspective (Gilbert et al. 2006).

Another issue to consider is the role that hybrid growth strategies, such as inter-firm alliances, play in promoting rapid growth in firms. Alliances can help alleviate the resource constraints in some smaller firms (Barringer et al. 2005), legitimise and serve as endorsements of a firm's technology (Dacin et al. 2007), and act as a conduit into overseas markets by reducing the socalled 'liability of foreignness' in external markets (Johanson and Vahlne 2009). Indeed, research in the UK's Cambridge high-tech cluster showed that HGFs have a higher proclivity

\footnotetext{
${ }^{11}$ This has been due in large part to (i) the inherent methodological complexities involved in differentiating organic growth from growth via acquisition when examining growth businesses using databases (Daunfeldt et al. 2015a) and (ii) that research on this issue has shown that organic growth is typically associated with smaller young firms whereas other non-organic growth modes are linked to larger more mature firms (Delmar et al. 2003).
} 
to establish alliances with other firms (Mohr et al. 2014). Other work examining the internationalisation processes of Scottish HGFs found that such strategic alliances enable firms to piggyback on pre-existing relationships, which helps them to become more internationally oriented (Mason et al. 2015). Furthermore, Brown and Mawson (2016b) found that informal alliances are, in some instances, a precursor to acquisitions.

Despite the prevalence of these external growth strategies, public policy currently pays little heed to fostering such external connections within HGFs, or looking to promote modes of growth outwith traditional organic growth. Indeed, to our knowledge no bespoke policy initiatives exist to promote entrepreneurial entry (or business growth in general) via acquisitions despite their fundamental importance for many HGFs (Mawson and Brown 2016). While there may be important displacement issues in terms of supporting firms wishing to undertake acquisitions, particularly domestically, there needs to be greater recognition amongst policy circles that entrepreneurial entry and firm growth is not solely an organic phenomenon.

\section{Myth \#7 HGFs are the same irrespective of their location}

In recent years, scholars have paid more attention to the localised environmental context mediating the entrepreneurial process (Welter 2011; Mason and Brown 2014; Welter et al. 2016). Recent research shows that although HGFs are found in all regions and in all types of geographical environments (large cities, small towns, rural areas), there are geographical clusters that account for a disproportionate number of these firms (Motoyama and Danley 2012; Rice et al. 2016). For example, a study of Dutch HGFs found they were disproportionately located in highly urban and accessible rural areas (Stam 2005). Given there seems a strong spatial logic to the geography of HGFs, further understanding of the local factors associated with the emergence and impacts of these firms is important for stimulating regional development (Li et al. 2016; Brown and Mawson 2016b).

While attempts have been made to examine the impact of HGFs across regions, a key assumption within UK policy circles is that HGFs have the same impact on job creation and wider economic development regardless of their regional location (Brown and Mason 2012), as evidenced from policy frameworks with identical targeting, support mechanisms, and expected outcomes from set programmes across spatial locations (see OECD 2013). On the 
face of it, there appears to be a universal approach towards HGFs, treating them the same irrespective of their physical location. This is reflected in similar policy approaches to support HGFs across most advanced economies. A benchmarking review of HGF public support programmes undertaken by the OECD found strong consistency across OECD countries in terms of client groups, the thematic nature of support and delivery structures (OECD 2013). Indeed, a strong thread running throughout these programmes was the lack of spatial customisation in terms of policy support. Many of the programmes reviewed were nationally rather than federally (or locally) administered, which could potentially undermine "the tailoring of the programme to local development needs" (OECD 2013, 29). Clearly, the support needs of a firm in rural lowa will be different to one in downtown Manhattan.

From recent academic studies, however, the economic impact of HGFs does appear to vary spatially. For example, Scottish HGFs have been found to create considerably fewer jobs on average than their UK counterparts, with the geography of the jobs created by HGFs far from localised (Brown and Mawson 2016b). As Scottish HGFs are more likely to have physical operations abroad than non-HGFs, the consequence is that as these firms grow, their employment and overall 'footprint' in their home region may diminish (Mason et al. 2015). Whilst further research is needed to fully explore the regional impacts of HGFs in a wider range of spatial contexts, the available evidence suggests that there might be marked regional variations in their economic impact. If, for example, a region has a strong manufacturing sector dominated by export-oriented manufacturing firms, local firms have the possibility to grow through exporting. In turn this will maintain their local employment base. A service sector firm, in contrast, may have no choice but to grow where their customers are located.

Policy makers therefore need to be cognisant of such variations, in order to ensure that interventions best address regional needs and guard against 'policy universalism' (Mason et al. 2015). This, however, goes against the strong emphasis on risk equity funding, universities, high-tech sectors and organic growth modes which are firmly embedded in high growth policies irrespective of the surrounding contextual environment. Whilst there appears to be a predilection to look to other geographies (e.g. Silicon Valley) for programmes and interventions to mimic at home, the empirical evidence base suggests caution in this regard, given the nuances of specific entrepreneurial contexts. Policy makers would be thus be better 
served by determining policy frameworks and programmes that best suit the needs of their own specific locations (Welter et al. 2011).

\section{Public Policy Frameworks and High Growth Firms}

It is clear from the preceding discussion that there is a critical misalignment between the institutional logic of HGF policy makers (linked to the current design of high growth entrepreneurship policies) and the developing evidence base on the nature of HGFs. Unfortunately space precludes a full examination of why and how this situation has arisen, including the workings underpinning policy formulation and implementation. It is important, however, to explore this misalignment in context and to identify how high growth entrepreneurship policy can - and should - be brought in line with the current evidence.

Many entrepreneurship policies are heavily shaped by the past and, as discussed, this is very much the case within the realm of high growth entrepreneurship. Indeed, there seem to be very strong path dependencies, where older policy programmes drawing on an older (nascent) evidence base are tweaked to become high growth programmes, not always reflecting developments in the knowledge base and our understanding of these firms. One such example is the aforementioned High Growth Spinout programme within Scotland, previously known as the Proof of Concept Programme, which aims to commercialise university IP. While the programme's name has changed in line with its new 'target market', it remains largely the same programme with the same overall aims and objectives. Ironically, reconfiguring interventions may in part stem from the increasing importance of measurement and project evaluation within public policy. Given their extreme heterogeneity and lack of uniformity, it is very difficult for policy makers to identify HGFs ex ante. Thus, a bias towards easily 'quantifiable' factors such as age, sector, receipt of venture capital and status as a USO is attractive to policy makers not only as a means of pre-selecting firms to engage with on policy programmes and other firm support mechanisms, but also to measure and quantify the outcomes and benefits of public expenditure.

The evidence documented within this paper has shown that the heterogeneous nature of HGFs strongly refutes the view held by some (Chan et al. 2006) that HGFs have homogeneous support needs. Indeed, this heterogeneity raises a number of key issues that should be 
reflected in future enterprise policies aimed at supporting growth-oriented firms. While not exhaustive, the following suggestions provide a basis for a much more realistic approach aimed at designing effective support to help germinate and grow more successful and, just as importantly, more sustainable growth firms. We have focused on a number of key thematic issues which could potentially help inform future policy making. While we suggest some alternative potential policy approaches, other areas also merit further consideration in light of the emerging evidence base. ${ }^{12}$

\subsection{Look beyond high-tech}

By prioritising support for high-tech firms, observers claim that policy makers are "looking in the wrong places" for HGFs (Mason and Brown 2013). Despite contributing only a small proportion of HGFs, high tech SMEs have been found to be the focus for a disproportionate range of available support options (Yoo et al. 2012; Autio and Rannikko 2016). Many of the current support systems for SMEs focus on more generic interventions such as R\&D assistance and financial support (OECD 2010), however firms operating in high-tech sectors of the economy are often able to access extra financial support from government programmes and higher education institutions for product design, technology development and innovation (Brown and Mason 2014). For example, analysis of data from the Scottish Co-Investment Fund, established to invest alongside business angel groups, reveals that three sectors (digital and enabling technologies, life science and renewables) together account for $80 \%$ of all expenditure by value (Scottish Enterprise 2012). This is also true for USOs, which often receive significant support under commercialisation policies such as proof-of-concept schemes and technology-transfer programmes operated by university technology transfer offices (Rothaermel 2007; Harrison and Leitch 2010; Brown 2016).

Of course, a lack of high-tech HGFs can be viewed in one of two ways. Some could suggest that these firms need (and indeed merit) more assistance to help them grow, especially given the knowledge spillovers and positive externalities generated by new technology-based firms (Storey and Tether 1998; Audretsch and Lehmann 2005). In other words, high-tech firms

\footnotetext{
12 Interestingly, a recent survey of HGFs found that $74 \%$ of HGFs ranked access to talent as one of their top three growth constraints compared to $22 \%$ that cited access to venture capital (Coutu 2014). While the literature on HGFs and HRM strategies is almost negligible (Demir et al. 2016), this would suggest that a key growth bottleneck for HGFs is effective recruitment and talent management.
} 
should be prioritised further to create more of them (Satterwaite and Hamilton 2016). Alternatively, a counterargument would be that if high-tech sectors provide relatively few HGFs it begs the question of why policy makers focus their efforts so strongly towards these sectors. In our view, high-tech firms probably do need different types of specialist support than more mundane firms. However, from our review we strongly believe that policy makers should avoid excessive sectoral prioritisation in support and we would caution against implicitly favouring high-tech firms through R\&D based eligibility criteria. Whilst support for high-tech firms is certainly warranted, and necessary, to promote a diverse business base (Satterthwaite and Hamilton 2016), these policies alone are unlikely to reach or generate more HGFs. Thus, policy makers should move away from the current high tech fixation to a more inclusive and nuanced view of where these firms originate from.

Support for growing firms therefore needs to reflect the diverse nature of their business activities, prioritising support for firms with growth ambitions and potential, rather than those with a particular sectoral or R\&D focus (Buss 2002; Bleda et al. 2013). The current focus on innovation should be extended to include a wider definition of the term. There is growing recognition of the importance of 'hidden' types of innovation, and that many HGFs procure from 'open sources' of innovation such as suppliers, customers and end-users (NESTA 2007; von Hippel 2009; NESTA 2010). Incorporating this wider view of innovation would in itself broaden support to a wider array of sectors, especially services. Interventions to foster stronger links with customers and end-users would be particularly beneficial, as research has identified that strong engagement with customers can be a powerful source of both innovation and firm growth (Mawson 2014).

Indeed, there is evidence to suggest that policy makers are becoming much more focused on taking a wider perspective within innovation policy (Warwick, 2013). This is evident in the overall thrust of the EU's wider regional policy framework of 'Smart Specialisation', which eschews high-tech initiatives and focuses more on promoting local entrepreneurial processes and upgrading the existing industrial fabric of regions (McCann and Ortega-Argilés 2015). Again, space does not permit a full assessment of this particular policy framework, particularly the ongoing debate about finding the 'optimal' levels of technological adoption and specialisation which we recognise as being very important. While top-down EU policy 
frameworks aspire policy makers to think more widely, local policy formulation often remains deeply at odds with these strategic aims. Indeed, in some locations regional innovation policy remains heavily focused on $R \& D$ and flagship initiatives as a means of creating more HGFs (Brown et al. 2015). This disconnect between policy actors at different spatial levels is likely one of the reasons why the 'myths' discussed remain present within public policy discourse and programming.

\subsection{Think about the timing of interventions}

The timing of interventions is a critical - but often overlooked - consideration. Some authors (Avnimelech and Teubal 2008) have developed the concept of 'evolutionary targeting', which focuses on market-led evolutionary development processes. This entails 'triggering and sustaining' the emergence of multi-agent structures to help nurture nascent new innovative industries (Avnimelech and Teubal 2008). While these arguments refer to how policy makers deal with nascent industries as a whole, the importance of temporal episodes also applies to firm-specific interventions. Given that many firms encounter 'trigger points' that instigate a period of organizational change (Brown and Mawson 2013), interventions focused on HGFs need to be responsive to time-sensitive company needs. Research has identified that firms enter a transition phase following a trigger point: the decisions, actions and processes undertaken during this time have a direct impact on whether firms will successfully capitalise on the trigger points and achieve growth (Brown and Mawson 2013). This is an ideal time for policy intervention, which could include, inter alia, support pre and post-acquisition, leadership development during and after a change in company management or leadership, or even advice on regulatory changes and legislation and their potential impact.

This approach would necessarily require a policy shift from reactive, time-bound assistance towards more temporal, flexible and proactive support mechanisms. It would undoubtedly be more people-intensive to deliver than larger-scale and more transactional initiatives such as financial assistance. However, to compensate for higher delivery costs, this kind of bespoke support could be heavily targeted. For example, rather than supporting a large number of high potential SMEs over a period of time as most public sector agencies do, short periods of in-depth engagement with a small number firms on the cusp of significant growth could be an alternative modus operandi for business support organisations. The costs of this kind of support could also be partly offset by financial contributions from supported firms. 
An added benefit of this kind of matched funding is the greater degree of organisational 'buyin' from firms this approach often engenders (OECD 2013).

\subsection{Focus on relational and peer-based support}

Growth-oriented firms often desire in-depth relational support more than financial assistance (Mason and Brown 2013), with HGFs preferring to obtain advice from their peers, rather than policymakers, intermediaries or consultants (Fischer and Reuber 2003). Relational rather than transactional aspects of support are thus crucial. Again, we do not recommend forgoing transactional support entirely, but rather to reconsider the balance between the two as, in light of empirical evidence, peer-based interventions are likely to be of significant benefit to growth businesses. Indeed, a number of the interventions such as the UK's (former) Growth Accelerator programme and the Companies of Scale programme in Scotland have strong peer-based elements built into these programmes (OECD 2013). ${ }^{13}$

Such relational elements could include, inter alia, using highly experienced entrepreneurs to help 'peer review' certain skills and competencies of other growing firms, 'implanting' successful entrepreneurs in high potential businesses to provide strategic guidance, and other networking activities. Mentoring by peers has been found to increase the entrepreneurial self-efficacy of less established entrepreneurs (Crompton et al. 2012). Growing firms could therefore be encouraged to develop 'peer' support through the use of non-executive directors, who are often a useful 'sounding board' to management teams. These forms of experiential learning would not only benefit the individuals and businesses involved, but also potentially a wider network of growth oriented businesses (Deakins and Freel 1998). Peerbased support approaches have obvious advantages for the public sector, as they are less expensive to operate than business mentoring through private sector intermediaries. An added advantage is the potential for networking and peer-based knowledge transfer. Peerbased support may also help temper the 'growth for growth's sake' attitude, which may be instilled in less experienced entrepreneurs and TMTs.

\footnotetext{
${ }^{13}$ As discussed earlier, the UK government terminated its flagship Growth Accelerator programme at the end of 2015.
} 


\subsection{Assistance with Ownership Change}

One aspect of public policy which is almost completely absent is support for ownership change. Research shows that MBOs, MBls and employee-buy outs often result in an existing business being reconfigured, which provides a fresh impetus to the 'reborn' business entity (Wright et al. 2001). More ambitious and growth-oriented entrepreneurs may have a strong preference for complex and high risk entry modes (Parker and Van Praag 2012). While business advisory services for start-ups are a commonly accepted part of the enterprise policy landscape (Bennett 2008), perhaps similar services could be provided for entrepreneurs seeking to undertake MBOs, MBIs or even an acquisition.

Acquisition can allow firms to quickly upscale and, in some cases, even ward off the threat of being acquired. Plus, non-organic growth can often be a precursor to a future period of organic growth (Lockett et al. 2011). Although traditionally associated with large firms, acquisitions appear to be of growing importance to innovative SMEs (Hussinger 2010), which comprise the future stock of HGFs. CEOs of SMEs therefore need to become better acquainted with the complex processes involved in successfully executing such transactions. Similarly, given the evidence noted on the strong role and usage of alliances, there is also the potential for greater support to foster these types of interactive relationships. With the exception of trying to foster links between firms and universities, policy rarely attempts to generate an external orientation within potential HGFs. However, it is now well established within the literature that alliances and strategic partnerships can be important mechanisms for knowledge creation, end-user engagement and overseas expansion (Mohr et al. 2014; Brown and Mawson 2016b). Given the importance of these types of relational connections, policy makers need to adopt systemic perspectives in assessing the support needs of HGFs (Mason and Brown 2014) rather than viewing them in isolation.

\subsection{Types of finance needed to fund high growth}

Finance in general is a critical issue for growing businesses and forms the "primary resource base from which other factor inputs are acquired" (Dobbs and Hamilton 2007, 306). To date, however, the volume of research on the funding issues within HGFs has been limited (Demir et al. 2016). Given its important role in enabling growth, financing for HGFs should be an important consideration, and arguably a cornerstone, of high growth entrepreneurship policy. At present, the primary focus of public policy in this area is the provision of venture 
capital. However, recent studies show that public sector venture capital is largely ineffective in promoting the growth of firms (Nightingale et al. 2009; Grilli and Murtinu 2014). Mason (2015) attributes this to several factors including an inappropriate investment focus (size of investments too small; technology orientation), the inability to provide larger follow-on investments, and lack of competence to provide hands-on support. Moreover, offering venture capital at too early a stage in the development of the business will dilute an entrepreneur's ownership, leaving them in a minority ownership position if further rounds of funding are required.

Given that funding issues make it difficult for firms "with high growth potential to realise their potential" (British Business Bank 2016, 6), policy-makers therefore need to rethink and redesign the delivery of government sponsored venture capital schemes and also develop other types of funding support across a wider range of different funding sources. One very cost effective solution is to help increase entrepreneurial financial literacy in rapidly growing firms. Help and support in assembling finance is considered to be one of the most important support needs of high potential firms (Smallbone et al. 2002). Indeed, stimulating the demand for external finance is an important objective to increase entrepreneurial ambition in firms. Research shows that entrepreneurs with higher levels of human capital and more extensive networks have a greater knowledge of financial options (Seghers et al. 2012). Therefore, improving the 'debt readiness' of growth-oriented firms may be a useful approach (Rostmakalaei and Freel 2016). Promoting newer forms of alternative finance such as crowdfunding could be another potential solution (Brown et al. 2015).

While unsuited to the majority of HGFs, equity finance is clearly crucial for some (Coutu 2014). In particular, there is a gap for investments in the $f 1 \mathrm{~m}$ - $f 10 \mathrm{~m}$ plus range (BERR 2008), which can be addressed by a combination of publicly funded but privately managed funds and the development of networks - or pipelines - to bring in out-of-region equity investors (Mason 2015). Connecting HGFs with exogenous sources of funding in this way could be an innovative and effective mechanism for counteracting the negative impact of HGFs who are located in so-called 'thin markets' evident in some peripheral regional economies (Nightingale et al. 2009). Interestingly, more innovative high growth programmes take such as an approach. The NIY programme operated by Tekes seeks to connect local Finnish firms with external 
investors (Autio and Rannikko 2016), which is a similar approach to the famous and highly regarded Yozma programme in Israel (Mason and Brown 2014). More imaginative approaches such as these are needed to help stimulate both the demand for - and supply of - finance within HGFs.

\section{Conclusion}

This debate article provides an important contribution to the entrepreneurship literature by dispelling some of the myths and assumptions embedded within high growth entrepreneurship policy. It makes further contributions to both the HGF literature and the entrepreneurship policy literature by highlighting how these myths have become translated into inappropriate policy initiatives.

The central argument put forward in the paper is that policy makers have selectively utilised and/or misinterpreted the evolving high growth literature, resulting in myths and misconceptions about these firms becoming deeply embedded within policy frameworks. In doing so, we have identified a clear mismatch between how policy makers perceive these firms and what they look like in reality. How this perceptual gap has emerged is less clear. We have speculated about some of the factors fostering the myth-building process in policy communities, but more research is needed to tease out the origins and antecedents of why myths become so firmly embedded and widely propagated.

We also demonstrate how these myths are strongly shaping the targeting of HGF policy (i.e. young and high-tech firms), thematic orientation of programmes (R\&D support and VC coinvestment schemes) and eligibility criteria (age of firms, university spin-outs, organic growers etc). These features are based on misconceptions of HGFs and do not correspond with the extreme heterogeneity exemplified within this diverse cohort of firms. We wish to stress that these myths are not applied universally by all policy makers in all contexts and in all programmes. Policy makers are, in some cases, starting to adjust their frameworks in light of the developing evidence base on HGFs, however this appears to be a very slow process. A lack of systematic, rigorous and holistic policy and programme level evaluations possibly enables these myths to endure (Stam et al. 2007). 
An important scholarly function is to question myths in order to prevent mistakes from being repeated (Gibb 2000; Rehn et al. 2013). With the level of cuts being made to public expenditure at the present time, it is more important than ever to push "aside false myths" about what the state can and cannot do to stimulate entrepreneurship (Mazzucato 2013, 198) whilst also challenging the exaggerated qualities attributed to entrepreneurship (Verduijn and Essers, 2013). While this paper has tackled one set of myths, there are undoubtedly "many more myths to challenge" within the realm of high growth entrepreneurship policy and entrepreneurship policy more generally (Rehn et al. 2013, 549). Not only will further myth-busting enhance scholarship within entrepreneurship, it will also aid the process of policy formulation and implementation. It is only by questioning basic assumptions and providing detailed empirical evidence that myths can be effectively challenged and progress can be made towards more effective policy making. 


\section{References}

Achtenhagen, L., L Naldi and L. Melin. 2010. "Business Growth - Do Practitioners and Scholars Really Talk About the Same Thing?" Entrepreneurship Theory \& Practice 34(2): 289-316.

Acs, Z. J., W. Parsons and S. Tracy. 2008. High-Impact Firms: Gazelles Revisited. Washington DC: Office of Advocacy of the US Small Business Administration (SBA).

Anyadike-Danes, M., K. Bonner and M. Hart. 2009. Measuring Business Growth: High Growth Firms and their Contribution to Employment in the UK., Research Report MBG/35. London: National Endowment for Science, Technology and the Arts (NESTA).

Anyadike-Danes, M., M. Hart and J. Du. 2015. "Firm dynamics and job creation in the United Kingdom: 1998-2013." International Small Business Journal 33(1): 12-27.

Atherton, A. 2006. "Should government be stimulating start-ups? An assessment of the scope for public intervention in new venture formation". Environment and Planning C: Government and Policy, 24(1): 21-36.

Audretsch, D. 2012. Determinants of High-Growth Entrepreneurship, Report prepared for the OECD/DBA International Workshop on "High-growth firms: local policies and local determinants", Copenhagen, 28 March, 2012.

Audretsch, D. B. and E. E. Lehmann. 2005. "Does the knowledge spillover theory of entrepreneurship hold for regions?" Research Policy, 34(8): 1191-1202.

Audretsch, D., E. Lehmann, M. Meoli and S. Vismara (Eds.) 2016. University evolution, entrepreneurial activity and regional competitiveness. Springer International Publishing.

Autio, E. and H. Rannikko. 2016. "Retaining winners: Can policy boost high-growth entrepreneurship?" Research Policy, 45(1): 42-55.

Autio, E., M. Kronlund and A. Kouvalainen. 2007. High-Growth SME Support Initiatives in Nine Countries: Analysis, Categorization and Recommendations, Report prepared for the Finnish Ministry of Trade and Industry, Helsinki.

Avnimelech, G. and M. Teubal. 2008. "Evolutionary targeting". Journal of Evolutionary Economics, 18(2): 151-166.

Baker, T. and R.E. Nelson. 2005. "Creating something from nothing: Resource construction through entrepreneurial bricolage". Administrative Science Quarterly, 50(3): 329-366.

Barringer, B. R., F. F. Jones and D. O. Neubaum. 2005. "A quantitative content analysis of the characteristics of rapid-growth firms and their founders." Journal of Business Venturing 20(5): 663-687. 
Baum, J. A. and B. S. Silverman. 2004. "Picking winners or building them? Alliance, intellectual, and human capital as selection criteria in venture financing and performance of biotechnology startups". Journal of business venturing, 19(3): 411-436.

Beck, T., A. Demirgüç-Kunt, and R. Levine. 2006. "Bank Supervision and Corruption in Lending." Journal of Monetary Economics, 53: 2131-63.

Bennett, R. 2008. "SME policy support in Britain since the 1990s: what have we learnt?" Environment and Planning C: Government and Policy 26: 375-397.

Berger, A. N. and G. E. Udell. 1998. "The economics of small business finance: The roles of private equity and debt markets in the financial growth cycle." Journal of Banking \& Finance, 22: 613-673.

BERR. 2008. High Growth firms in the UK: Lessons from an analysis of comparative UK performance, BERR Economics Paper No.3. London: Department for Business Enterprise \& Regulatory Reform (BERR) [http://www.berr.gov.uk/files/file49042.pdf].

Bhidé, A. 1991. "Bootstrap finance: the art of start-ups". Harvard Business Review, 70(6), 109117.

Bhidé, A. 2008. The Venturesome Economy: How Innovation Sustains Prosperity in a More Connected World. Princeton: Princeton University Press.

Birch, D. 1979. The Job Generation Process. Cambridge, MA: M.I.T. Program on Neighbourhood and Regional Change.

Birch, D. and J. Medoff. 1994. "Gazelles", in Solomon, L., Levenson A. (Eds) Labor Markets, Employment Policy, and Job Creation, Westview Press, Boulder. Pp. 159-168.

Birch, D. L. 1981. "Who creates jobs?" The public interest, (65): 3.

Bleda, M., K. Morrison and J. Rigby. 2013. "The Role and Importance of Gazelles and Other Growth Firms for Innovation and Competitiveness." In Innovation Policy Challenges for the 21st Century, edited by D. Cox and J. Rigby, pp. 36-63. London: Routledge.

Bos, J. W. B. and E. Stam. 2014. "Gazelles and industry growth: a study of young high-growth firms in The Netherlands", Industrial and Corporate Change 23: 145-169.

Brännback, M., A. L. Carsrud and N. Kiviluoto. 2013. Understanding the Myth of High Growth Firms: The Theory of the Greater Fool. Springer Science \& Business Media.

Brännback, M., N. Kiviluoto, A. Carsrud and R. Östermark. 2011. "Much Ado About Nearly Nothing? An Exploratory Study on the Myth of High Growth Technology Start-Up Entrepreneurship", Frontiers of Entrepreneurship Research 30: 1-14.

British Business Bank. 2016. Small Business Finance Markets, British Business Bank, Sheffield.

Brown, R. 2016. "Mission impossible? Entrepreneurial universities and peripheral regional innovation systems". Industry and Innovation, 23(1): 1-17.

Brown, R. and C. Mason. 2012. "Raising the batting average: Re-orientating regional industrial policy to generate more high growth firms", Local Economy, 27(1): 33-49.

Brown, R. and C. Mason. 2014. "Inside the high-tech black box: A critique of technology entrepreneurship policy", Technovation 34: 773-784. 
Brown, R. and N. Lee, N. 2014. An Examination of Funding Issues Confronting High Growth SMEs in the UK. Edinburgh: Institute for Chartered Accountants in Scotland (ICAS).

Brown, R., G. Gregson and C. Mason. 2015. "A Post-Mortem of Regional Innovation Policy Failure: Scotland's Intermediate Technology Initiative (ITI)". Regional Studies, 1-13.

Brown, R. and S. Mawson. 2013. "Trigger points and high-growth firms: A conceptualisation and review of public policy implications", Journal of Small Business and Enterprise Development 20(2): 279-295.

Brown, R. and S. Mawson. 2016a. "Targeted Support for High Growth Firms: Theoretical Constraints, Unintended Consequences and Future Policy Challenges." Environment and Planning C: Government and Policy, 34(5): 816-836.

Brown, R. and S. Mawson. 2016b. "The Geography of Job Creation in High Growth Firms: The Implications of 'Growing Abroad'", Environment and Planning C: Government and Policy, 34(3): 207-227.

Brown, R., Mawson, S. \& Lee, N. (2017). High Growth Firms in Northern Ireland: A Strategic Appraisal and Policy Assessment, Final Report for Department for the Economy, Northern Ireland.

Brüderl, J. and P. Preisendörfer. 2000. "Fast-growing businesses: empirical evidence from a German study". International Journal of Sociology, 30(3): 45-70.

Bruneel, J., B. Clarysse and A. Groen. 2012. "The Evolution of Business Incubators: Comparing demand and supply of business incubation services across different incubator generations" Technovation 32: 110-121

Buss, T. 2002. "Emerging High Growth Firms and Economic Development Policy", Economic Development Quarterly 16: 17-19.

Chan, Y. E., N. Bhargava and C. T. Street. 2006. "Having Arrived: The Homogeneity of HighGrowth Small Firms". Journal of Small Business Management, 44(3): 426-440.

Churchill, N. C. and V. L. Lewis. 1983. "The Five Stages of Small Business Growth." Harvard Business Review 61: 30-50.

Coad A, S-O. Daunfeldt, W. Hölzl, D. Johansson and P. Nightingale. 2014. "High-growth firms: introduction to the special issue." Industrial and Corporate Change 23: 91-112.

Coad, A. and R. Rao. 2008. "Innovation and firm growth in high-tech sectors: A quantile regression approach." Research Policy, 37(4): 633-648.

Coad, A. 2007. "A closer look at serial growth rate correlation." Review of Industrial Organization, 31: 69-82.

Coad, A. 2009. The Growth of Firms: A Survey of Theories and Empirical Evidence. Cheltenham: Edward Elgar.

Coad, A., J. Frankish, R. G. Roberts and D. J. Storey. 2013. "Growth paths and survival chances: An application of Gambler's Ruin theory." Journal of Business Venturing 28(5): 615-632.

Colombelli, A., J. Krafft and F. Quatraro. 2014. "High-growth firms and technological knowledge: do gazelles follow exploration or exploitation strategies?." Industrial and Corporate Change 23(1): 261-291. 
Coutu, S. 2014. "The Scale Up Report on UK Economic Growth. Information Economy Council. Credit Suisse. 2012. From David to Goliath: How Entrepreneurs Overcome the Challenges of Company Growth, White Paper 04, Prepared by the Lloyd Center for Entrepreneurial Studies at the Marshall School of Business, University of Southern California for Credit Suisse.

Crompton, B., K. Smyrnios and R. Bi. 2012. "Measuring the Influence of Business Coaching on Fast Growth Firms". Small Enterprise Research 19: 16-31.

Dacin, M. T., C. Oliver and J. P. Roy. 2007. "The legitimacy of strategic alliances: An institutional perspective". Strategic Management Journal, 28(2), 169-187.

Daunfeldt, S. O. and D. Halvarsson. 2015. "Are high-growth firms one-hit wonders? Evidence from Sweden”. Small Business Economics 44: 361-383.

Daunfeldt, S. O., D. Johansson and D. Halvarsson. 2015a. "Using the Eurostat-OECD definition of high-growth firms: a cautionary note." Journal of Entrepreneurship and Public Policy 4(1): 50-56.

Daunfeldt, S. O., N. Elert and D. Johansson. 2014. "The Economic Contribution of High-Growth Firms: Do Policy Implications Depend on the Choice of Growth Indicator?" Journal of Industry, Competition and Trade, 14: 337-365.

Daunfeldt, S. O., N. Elert and D. Johansson. 2015b. "Are high-growth firms overrepresented in high-tech industries?" Industrial and Corporate Change, dtv035.

Davila, A., G. Foster and M. Gupta. 2003. "Venture capital financing and the growth of startup firms". Journal of Business Venturing, 18(6): 689-708.

Deakins, D. and M. Freel. 1998. "Entrepreneurial learning and the growth process in SMEs." The Learning Organization 5: 144-155.

Decker, R. A., J. Haltiwanger, R. S. Jarmin and J. Miranda. 2015. Where has all the skewness gone? The decline in high-growth (young) firms in the US (No. w21776). National Bureau of Economic Research.

Deiaco, E., A. Hughes and M. McKelvey. 2012. "Universities as strategic actors in the knowledge economy". Cambridge Journal of Economics, 36(3): 525-541.

Delmar, F., A. McKelvie and K. Wennberg. 2013." Untangling the relationships among growth, profitability and survival in new firms". Technovation, 33(8): 276-291.

Delmar, F., P. Davidsson and W. B. Gartner. 2003. "Arriving at the high-growth firm." Journal of Business Venturing 18: 189-216.

Demir, R., Wennberg, K. and A. McKelvie. 2016. "The Strategic Management of High-Growth Firms: A Review and Theoretical Conceptualization." Long Range Planning. Available online doi.org/10.1016/j.Irp.2016.09.004

Deschryvere, M. 2008. High growth firms and job creation in Finland (No. 1144). ETLA discussion paper. Helsinki: The Research Institute of the Finnish Economy (ETLA). [https://www.etla.fi/wp-content/uploads/2012/09/dp1144.pdf]

Dobbs, M. and R. Hamilton. 2007. "Small Business growth: Recent evidence and new directions." Journal of Entrepreneurial Behaviour \& Research 13: 296-322. 
Du, J. and Y. Temouri. 2015. "High-growth firms and productivity: evidence from the United Kingdom." Small Business Economics 44(1): 123-143.

Fischer, E. and A. R. Reuber. 2003. "Support for Rapid-Growth Firms: A Comparison of the Views of Founders, Government Policymakers, and Private Sector Resource Providers." Journal of Small Business Management 41: 346-365.

Flanagan, K., E. Uyarra and M. Larnaja. 2011. "Reconceptualising the 'policy mix' for innovation." Research Policy 40: 702-713.

Frank, H., \& Landström, H. (2016). What makes entrepreneurship research interesting? Reflections on strategies to overcome the rigour-relevance gap. Entrepreneurship \& Regional Development, 28(1-2), 51-75.

Freel, M. 1998. "Policy, prediction and growth: Picking start-up winners?" Journal of Small Business and Enterprise Development 5: 19-32.

Friedland, R. and R. R. Alford. 1991 "Bringing Society Back in: Symbols, Practices, and Institutional Contradictions". In The New Institutionalism in Organizational Analysis, edited by W.W. Powell and P. J. DiMaggio, pp. 232-63. Chicago, IL: University of Chicago Press.

Fritsch, M. and D. Storey. 2014. "Entrepreneurship in a Regional Context: Historical Roots, Recent Developments and Future Challenges", Regional Studies 48: 939-954.

Garnsey, E. 1998. "A theory of the early growth of the firm", Industrial and Corporate Change, 7(3), 523-556.

Garnsey, E. and P. Heffernan. 2005. "High-technology clustering through spin-out and attraction: The Cambridge case". Regional Studies, 39(8): 1127-1144.

Garnsey, E., E. Stam and P. Heffernan. 2006. "New firm growth: Exploring processes and paths", Industry and Innovation 13: 1-20.

Gartner, W. B. 2007. Is there an elephant in entrepreneurship? Blind assumptions in theory development. In Entrepreneurship (pp. 229-242). Springer Berlin Heidelberg.

Gibb, A. A. 2000. "SME policy, academic research and the growth of ignorance, mythical concepts, myths, assumptions, rituals and confusions", International Small Business Journal, 18(3): 13-35.

Gilbert, B., P. McDougall and D. Audretsch. 2006. "New venture growth: A review and extension", Journal of Management 25: 751-778.

Goedhuys, M. and L. Sleuwaegen. 2010. "High-growth entrepreneurial firms in Africa: a quantile regression approach", Small Business Economics 34: 31-51.

Greene, F. 2012. Should the focus of publicly provided small business assistance be on startups or growth businesses?, Occasional Paper 12/02. Auckland, New Zealand: Ministry of Economic Development.

Grilli, L. and S. Murtinu. 2014. "Government, venture capital and the growth of European high-tech entrepreneurial firms", Research Policy 43(9): 1523-1543.

Hambrick, D. C. and L. M. Crozier. 1986. "Stumblers and stars in the management of rapid growth." Journal of Business Venturing 1(1): 31-45. 
Harrison, R. and C. Leitch. 2010. "Voodoo Institution or Entrepreneurial University? Spin-Off Companies, the Entrepreneurial System and Regional Development in the UK." Regional Studies, 44: 1241-1262.

Hellmann, T. and M. Puri. 2000. The interaction between product market and financing strategy: The role of venture capital. Review of Financial studies, 13(4), 959-984.

Henrekson, M. and D. Johansson. 2010. "Gazelles as job creators: a survey and interpretation of the evidence", Small Business Economics 35(2): 227-244.

Hinton, M. and R. T. Hamilton. 2013. "Characterising high-growth firms in New Zealand", The International Journal of Entrepreneurship and Innovation 14: pp. 39-48.

Hirunyawipada, T. and A.K. Paswan. 2013. "Effects of team cognition and constraint on new product ideation", Journal of Business Research 66(11): 2332-2337.

Hölzl, W. 2014. "Persistence, survival, and growth: a closer look at 20 years of fast-growing firms in Austria", Industrial and Corporate Change 23: 199-231.

Hsu, D. H. 2007. “Experienced entrepreneurial founders, organizational capital, and venture capital funding", Research Policy, 36(5): 722-741.

Hussinger, K. 2010. "On the importance of technological relatedness: SMEs versus large acquisition targets", Technovation 30: 57-64.

Johanson, J. and J. E. Vahlne. 2009. "The Uppsala internationalization process model revisited: From liability of foreignness to liability of outsidership", Journal of International Business Studies, 40(9): 1411-1431.

Kingdon, J. W. 1984. Agendas, alternatives and public policies. New York: Harper Collins.

Kiviluoto, N. (2013). Growth as evidence of firm success: myth or reality?. Entrepreneurship \& Regional Development, 25(7-8), 569-586.

Krasniqi, B. A. and S. Desai. 2016. "Institutional drivers of high-growth firms: country-level evidence from 26 transition countries." Small Business Economics First Online: 06 May 2016 DOI: 10.1007/s11187-016-9736-7.

Lee, N. 2014. "What holds back high-growth firms? Evidence from UK SMEs", Small Business Economics 43: 183-195.

Lee, N., R. Brown and T. Schueslter. 2016. Modes of Firm growth, ERC Research Paper 46, http://www.enterpriseresearch.ac.uk/wp-content/uploads/2016/05/ERC-ResPap46-

LeeBrownSchlueter-RBNL_acks.pdf

Leitch, C., F. Hill and H. Neergaard. 2010. "Entrepreneurial and business growth and the quest for a "comprehensive theory": tilting at windmills?", Entrepreneurship Theory and Practice 34(2): 249-260.

Lerner, J. 2009. Boulevard of broken dreams: why public efforts to boost entrepreneurship and venture capital have failed--and what to do about it. Princeton University Press.

Levie, J. and B. Lichstenstein. 2010. "A Terminal Assessment of Stages Theory: Introducing a Dynamic States Approach towards Entrepreneurship", Entrepreneurship Theory and Practice 34: 317-350. 
Li, M., S. J. Goetz, M. Partridge and D. A. Fleming. 2016. "Location determinants of highgrowth firms." Entrepreneurship \& Regional Development, 28 (1-2): 97-125.

Lockett, A., J. Wiklund, P. Davidsson and S. Girma. 2011. "Organic and Acquisitive Growth: Reexamining Testing and Extending Penrose's Growth Theory". Journal of Management Studies 48: 48-74.

Martin, R., C. Berndt, B. Klagge and P. Sunley. 2005. „Spatial proximity effects and regional equity gaps in the venture capital market: evidence from Germany and the United Kingdom." Environment and Planning A, 37(7): 1207-1231.

Mason, C. 2015. "Promoting entrepreneurship in peripheral regions: the limits to public sector venture capital funds". Paper to the First Learned Society of Wales International Symposium. Economic Policies in Peripheral Countries. Portmeirion, Wales, 13-15 April.

Mason, C. and R. Brown. 2013. "Creating good public policy to support high growth firms", Small Business Economics 40 (2): 211-225.

Mason, C. and R. Brown. 2014. Entrepreneurial Ecosystems and Growth-Oriented Entrepreneurship. Paris: Organisational for Economic Co-operation and Development (OECD).

Mason, C., R. Brown, M. Hart and M. Anyadike-Danes. 2015. "High growth firms, jobs and peripheral regions: the case of Scotland", Cambridge Journal of Regions, Economy and Society, 8 (2): 359-377.

Mawson, S. 2012. Data Analysis on Acquisitions and High Growth Firms. A report for Scottish Enterprise, Glasgow.

Mawson, S. 2014. "Exploring rapid firm growth: Customer perceived value in high growth firms." Paper presented at RENT Conference XXV111, Luxembourg, November 19-21.

Mawson, S. and R. Brown. 2016. Entrepreneurial acquisitions, open innovation and UK high growth SMEs". Industry and Innovation, Available online first doi.org/10.1080/13662716.2016.1244764

Mazzucato, M. 2013. The Entrepreneurial State. London: Anthem Press.

Mazzucato, M. and S. Parris. 2015. "High-growth firms in changing competitive environments: the US pharmaceutical industry (1963 to 2002)", Small Business Economics, 44(1): 145-170.

McCann, P. and R. Ortega-Argilés. 2015. "Smart specialization, regional growth and applications to European Union cohesion policy", Regional Studies, 49(8): 1291-1302.

McKelvie, A. and J. Wiklund. 2010. "Advancing Firm Growth Research: A Focus on Growth Mode Instead of Growth Rate", Entrepreneurship Theory and Practice 34: 261-288.

Miller, S.M., A. Hoffer and D. Wille. 2016. Small-Business Financing after the Financial Crisis: Lessons from the Literature, Mercatus Working Paper.

Ministry of Business, Innovation \& Employment. 2013. High-growth businesses in New Zealand. Ministry of Business, Innovation \& Employment.

Mohr, V., E. Garnsey and G. Theyel. 2014. "The role of alliances in the early development of high growth firms", Industrial and Corporate Change 23: 233-259.

Moreno, A. M. and J. C. Casillas. 2007. "High-growth SMEs versus non-high-growth SMEs: a discriminant analysis", Entrepreneurship and Regional Development, 19(1): 69-88. 
Moreno, F. and A. Coad. 2015. High-Growth Firms: Stylized Facts and Conflicting Results, Working Paper Series SWPS 2-15-05 (February) SPRU, University of Sussex.

Motoyama, Y. and B. Danley. 2012. An Analysis of the Geography of Entrepreneurship: Understanding the Geographic Trends of Inc. 500 Companies Over Thirty Years at the State and Metropolitan Levels. Kansas City: Ewing Marion Kauffman Foundation [http://dx.doi.org/10.2139/ssrn.2145480]

Myers, S. C. and N. S. Majluf. 1984. "Corporate financing and investment decisions when firms have information that investors do not have". Journal of Financial Economics, 13(2): 187-221.

NESTA. 2007. Hidden innovation: How innovation happens in six 'low innovation' sectors. London: National Endowment for Science, Technology and the Arts (NESTA).

NESTA. 2009. The vital 6 per cent: How high-growth innovative businesses generate prosperity and jobs. London: National Endowment for Science, Technology and the Arts (NESTA).

NESTA. 2010. Demand and Innovation: How customer preferences shape the innovation process. London: National Endowment for Science, Technology and the Arts (NESTA).

Nicholls-Nixon, C. L. 2005. "Rapid growth and high performance: The entrepreneur's "impossible dream?", The Academy of Management Executive 19(1): 77-89.

Nightingale, P. and A. Coad. 2014. "Muppets and Gazelles: political and methodological biases in entrepreneurship research", Industrial and Corporate Change 23: 113-143.

Nightingale, P., G. Murray, M. Cowling, C. Baden-Fuller, C. Mason, J. Siepel, and C. Dannreuther. 2009. From funding gaps to thin markets: UK Government support for earlystage venture capital. London: National Endowment for Science, Technology and the Arts (NESTA).

OECD. 2008. Measuring Entrepreneurship: A Digest of Indicators. Paris: OECD-Eurostat Entrepreneurship Indicators Program, Organisational for Economic Co-operation and Development (OECD).

OECD. 2010. High-growth enterprises: What governments can do to make a difference. OECD studies on SMEs and entrepreneurship. Paris: Organisational for Economic Co-operation and Development (OECD).

OECD. 2011. Financing High Growth Firms: The Role of Angel Investors. Paris: Organisational for Economic Co-operation and Development (OECD).

OECD. 2013. An international benchmarking analysis of public programmes for high-growth firms. Paris: OECD LEED programme.

O'Regan, N., A. Ghobadian and D. Gallear. 2006. "In search of the drivers of high growth in manufacturing SMEs". Technovation, 26(1): 30-41.

Parker, S. C., D. J. Storey and A. Van Witteloostuijn. 2010. "What happens to gazelles? The importance of dynamic management strategy", Small Business Economics, 35(2): 203-226.

Parker, S.C. and M. Van Praag. 2012. "The entrepreneur's mode of entry: Business takeover or new venture start?" Journal of Business Venturing 27(1): 31-46.

Phelps, R., Adams, R. and J. Bessant. 2007. "Life cycles of growing organizations: A review with implications for knowledge and learning", International Journal of Management Reviews, 9(1): 1-30. 
Power, D. and A. Malmberg. 2008. "The contribution of universities to innovation and economic development: in what sense a regional problem?" Cambridge Journal of Regions, Economy and Society 1(2): 233-245.

Rehn, A., M. Brännback, A. Carsrud and M. Lindahl. 2013. "Challenging the myths of entrepreneurship?" Entrepreneurship \& Regional Development 25(7-8): 543-551.

Rice, M. D., D. I. Lyons and S. B. O'Hagan. 2015. “Fast-growing firms as elements of change in Canada's headquarters city system". Urban Geography, 36(6): 844-863.

Rice, M., V. Oppenheim, C. Tiwari, S. O’Hagan, D. Lyons and M. Green. 2016. “Defining the Record of High-Growth Firms by US Metropolitan Region: What Happens to the Inc 500?" Paper presented at the American Association of Geographers Annual Conference in San Francisco, $29^{\text {th }}$ March-2 ${ }^{\text {nd }}$ April.

Roper, S. and M. Hart. 2013. Supporting Sustained Growth Among SMEs - Policy Models and Guidelines. ERC White Paper No 7. Birmingham: Enterprise Research Centre (ERC). [http://enterpriseresearch.ac.uk/default/assets//File/ERC\%20White\%20Paper\%20No\%20\%2 07\%20Roper\%20\%20Hart\%20Supporting\%20sustained\%20growth\%202.pdf]

Rostamkalaei, A. and M. Freel. 2016. "The cost of growth: small firms and the pricing of bank loans." Small Business Economics, 46(2): 255-272.

Rothaermel, F., S. Agung and L. Jiang. 2007. "University entrepreneurship: a taxonomy of the literature". Industrial and Corporate Change 16: 691-791.

Satterthwaite, S. and R. T. Hamilton. 2016. "High-growth firms in New Zealand: Superstars or shooting stars?" International Small Business Journal Published online before print July 29, 2016, doi: 10.1177/0266242616659913.

Scales (2007) High-Growth Support Initiatives, Report published under the Scales-initiative as part of the "SMEs and Entrepreneurship programme financed by the Netherlands Ministry of Economic Affairs.

Scottish Enterprise. 2012. The Risk Capital Market in Scotland 2009-2011. Scottish Enterprise, Glasgow.

Segarra, A. and M. Teruel. 2014. "High-growth firms and innovation: an empirical analysis for Spanish firms." Small Business Economics 43(4): 805-821.

Seghers, A., S. Manigart and T. Vanacker. 2012. "The impact of human and social capital on entrepreneurs' knowledge of finance alternatives." Journal of Small Business Management, 50(1): 63-86.

Senderovitz, M., K. Klyver and P. Steffens. 2015. "Four years on: Are the gazelles still running? A longitudinal study of firm performance after a period of rapid growth". International Small Business Journal, Published online before print February 2, 2015, doi: 10.1177/0266242614567483.

Shane, S. 2009. "Why encouraging more people to become entrepreneurs is bad public policy". Small Business Economics 33: 141-149.

Shane, S. and D. Cable, D. 2002. "Network ties, reputation, and the financing of new ventures". Management Science, 48(3): 364-381. 
Smallbone, D., R. Balddock and S. Burgess. 2002. "Targeted support for high-growth start-ups: some policy issues". Environment and Planning C: Government and Policy 20: 195-209.

Spigel, B. 2015. "The Relational Organization of Entrepreneurial Ecosystems". Entrepreneurship Theory and Practice. Published online first: DOI: 10.1111/etap.12167

Stam, E. 2005. "The geography of gazelles in the Netherlands." Tijdschrift voor Economische en Sociale Geografie 96(1): 121-127.

Stam, E., K. Suddle, J. Hessels and A. J. Van Stel. 2007. High growth entrepreneurs, public policies and economic growth. Jena Economic Research Paper, (2007

Storey, D. J. and B. S. Tether. 1998. "New technology-based firms in the European Union: an introduction." Research Policy, 26(9): 933-946.

van der Schans, D. 2015. "The British Business Bank's role in facilitating economic growth by addressing imperfections in SME finance markets." Venture Capital (ahead-of-print): 1-19.

Vanacker, T. R. and S. Manigart. 2010. "Pecking order and debt capacity considerations for high-growth companies seeking financing". Small Business Economics 35(1): 53-69.

Verduijn, K., \& Essers, C. (2013). Questioning dominant entrepreneurship assumptions: the case of female ethnic minority entrepreneurs. Entrepreneurship \& Regional Development, 25(7-8), 612-630.

von Hippel, E. 2009. "Democratizing Innovation: The Evolving Phenomenon of User Innovation." International Journal of Innovation Science 1: 29-40.

Warwick, K. 2013. Beyond Industrial Policy: Emerging Issues and New Trends. OECD Science, Technology and Industry Policy Papers, No. 2. Paris: Organisational for Economic Cooperation and Development (OECD).

Welter, F. 2011. "Contextualizing entrepreneurship-conceptual challenges and ways forward." Entrepreneurship Theory and Practice 35: 165-184.

Welter, F., T. Baker, D. Audretsch and W. B. Gartner. 2016. "Everyday Entrepreneurship-A Call for Entrepreneurship Research to Embrace Entrepreneurial Diversity." Entrepreneurship Theory and Practice. DOI: 10.1111/etap.12258

Wennberg, K. 2013. "Managing High Growth Firms: A Literature review." Background Paper for OECD LEED Programme Workshop on "Management and Leadership Skills in High-Growth Firms", Warsaw.

Wennberg, K., J. Wiklund and M. Wright. 2011. "Academic entrepreneurship: Performance differences between university spin-offs and corporate spin-offs." Research Policy 40: 11281143.

World Economic Forum (2014) Global Entrepreneurship and the Successful Growth Strategies of Early-Stage Companies, World Economic Forum, Davos.

Wright, M., R. Hosskinson and L. Busenitz. 2001. "Firm rebirth: Buyouts as facilitators of strategic growth and entrepreneurship." Academy of Management Perspectives 15: 111-125.

Xheneti, M. (2016). Contexts of enterprise policy-making-an institutional perspective. Entrepreneurship \& Regional Development, 1-23. 
Yoo, S. J., N. G. Mackenzie and D. Jones-Evans. 2012. "Public sector support and technologybased SMEs in peripheral areas - the case of North Wales." Journal of Enterprising Culture 20: 83-104.

Zahra, S. A. and W. D. Schulte. 1994. "International entrepreneurship: Beyond myth and folklore." International Journal of Commerce and Management 4(1/2): 85-95.

Zhang, Y., X. Yang and F. Ma. 2008. "A quantitative analysis of the characteristics of rapidgrowth firms and their entrepreneurs in China." Journal of Small Business and Enterprise Development 15(4): 675-688. 